\title{
Ectopic expression of AtPAD4 broadens resistance of soybean to soybean cyst and root-knot nematodes
}

\author{
Reham M Youssef ${ }^{1,3}$, Margaret H MacDonald ${ }^{1}$, Eric P Brewer ${ }^{1}$, Gary R Bauchan ${ }^{1}$, Kyung-Hwan Kim² \\ and Benjamin F Matthews ${ }^{1 *}$
}

\begin{abstract}
Background: The gene encoding PAD4 (PHYTOALEXIN-DEFICIENT4) is required in Arabidopsis for expression of several genes involved in the defense response to Pseudomonas syringae pv. maculicola. AtPAD4 (Arabidopsis thaliana PAD4) encodes a lipase-like protein that plays a regulatory role mediating salicylic acid signaling.

Results: We expressed the gene encoding AtPAD4 in soybean roots of composite plants to test the ability of AtPAD4 to deter plant parasitic nematode development. The transformed roots were challenged with two different plant parasitic nematode genera represented by soybean cyst nematode (SCN; Heterodera glycines) and root-knot nematode (RKN; Meloidogyne incognita). Expression of AtPAD4 in soybean roots decreased the number of mature SCN females 35 days after inoculation by 68 percent. Similarly, soybean roots expressing AtPAD4 exhibited 77 percent fewer galls when challenged with RKN.
\end{abstract}

Conclusions: Our experiments show that AtPAD4 can be used in an economically important crop, soybean, to provide a measure of resistance to two different genera of nematodes.

Keywords: Arabidopsis, Phytoalexin-deficient4, AtPAD4, Soybean, Nematodes, Salicylic acid, Plant defense

\section{Background}

Inducible defense responses are activated when plants respond to pathogen attack [1]. The gene-for-gene defense response is a strong form of plant resistance against pathogens. This type of resistance is turned on when the plants have a specific resistance $(R)$ gene that recognizes the product of a corresponding pathogen gene known as the avirulence (avr) gene. This interaction between an $R$-gene and an $a v r$-gene triggers the hypersensitive response (HR) and rapid expression of defense responses that result in programmed cell death within $24 \mathrm{~h}$ of infection [2]. Another type of defense response occurs after attack by virulent pathogens that do not have an avr-gene recognized by the plant. In this case, the plant responds more slowly than in gene-for -gene resistance, allowing the pathogen to multiply. Resistance to virulent pathogens can occur through a

\footnotetext{
* Correspondence: ben.matthews@ars.usda.gov

${ }^{1}$ USDA-ARS, Soybean Genomic and Improvement Laboratory, 10300

Baltimore Ave, Bldg 006, Beltsville, MD 20705, USA

Full list of author information is available at the end of the article
}

phenomenon called systemic acquired resistance (SAR) [3], which occurs after the hypersensitive response. SAR reduces symptoms produced by a variety of pathogens, but not by all pathogens [4]. Salicylic acid (SA) plays a central signaling role in both gene-for-gene resistance and SAR. This role for SA was proven by construction of transgenic plants expressing a bacterial salicylate hydroxylase gene (nahG) that converts SA to catechol [5]. During gene-for-gene resistance or infection with virulence pathogens, the $n a h G$ plants failed to express pathogenesis related $(P R)$ genes, and their susceptibility to both virulent and avirulent pathogens was greatly enhanced $[5,6]$.

Mutants of the model plant Arabidopsis thaliana have been used for studying SA-dependent regulation of plant defense responses. Production of certain defense signals is controlled by the Arabidopsis PAD4 (AtPAD4) gene. Plants carrying $P A D 4$ mutations displayed reduced levels of SA, decreased expression of the defense gene $P R 1$, and reduced synthesis of the indole derivative, camalexin, after infection with a virulent strain of Pseudomonas syringae 
[7-10]. In contrast, the role of PAD4 in defense against the green peach aphid Myzus persicae Sulzer is independent of SA and camalexin [10,11]. Reported that PAD4 encodes a nucleo-cytoplasmic protein which has similarity to triacyl glycerol lipases and other esterases. In defense signaling, PAD4 acts in conjunction with the EDS1 gene (ENHANCED DISEASE SUSCEPTIBILITY1), which encodes a structurally related protein also found in the nucleus and cytoplasm [12,13]. EDS1 is required for accumulation of PAD4 protein [14]. EDS1 also interacts with another lipase-like protein, SAG101 (SENESCENCEASSOCIATED GENE101), which accumulates in the nucleus [13]. The occurrence of EDS1-PAD4 and EDS1SAG101 complexes inside plant cells suggests that EDS1 works as an adaptor for both PAD4 and SAG101 in defense signaling [13].

Although PAD4 has been extensively studied in Arabidopsis, less is known about its role in conferring resistance to nematodes, and it is not known if AtPAD4 can function in economically important crops, such as soybean, to provide resistance to nematodes. The soybean cyst nematode (SCN; Heterodera glycines) and the root-knot nematode (RKN; Melidogyne incognita) are obligatory plant parasites that are responsible for more than 100 billion U. S. dollars in yield losses annually of economic crops worldwide [15]. Both nematode species establish complex feeding sites within their host plants. At infection, the pre-parasitic second stage juveniles (J2) penetrate the roots and migrate towards the vascular cylinder where they induce the growth of a multinuclear feeding site, termed a 'syncytium' produced by SCN and a 'giant cell' produced by RKN [16].

The SCN life cycle, which can be completed in about 30 days under optimum conditions, includes six stages: the egg, four juvenile stages, and the adult [17]. The only stage to infect plant roots is the $\mathrm{J} 2$, which is motile and typically penetrates the host root and migrates to the vascular cylinder while secreting cell-wall degrading enzymes [18-21]. Once there, the nematode injects proteins into a host cell through its stylet, inducing formation of the syncytium [22-26]. Many physiological and morphological changes occur during formation of the syncytium: surrounding cell walls partially dissolve, nuclei enlarge, the density of organelles in the cytoplasm increases, and there is an accumulation of endoplasmic reticulum [24,27,28]. Initiation and formation of the syncytium is a complicated process requiring an unknown host signal transduction pathway triggered by secretions from the nematode esophageal glands $[18,20]$. After the feeding site is initiated, the J2 molts to the J3 and J4 stages before finally developing into a female or male adult. The female remains sedentary at the feeding site while the mature male becomes mobile in the root to fertilize the female. The female extracts nourishment from the syncytium to support the production of several hundred eggs, most of which stay inside the female's body, while others are excreted as a gelatinous mass into the soil. After the female dies, the body remains intact and hardens into a tough leathery sac known as a cyst. Eggs and larvae can survive in the cyst body for several years until they are stimulated to hatch in the soil under favorable conditions $[18,25,26]$.

The life cycle of RKN varies from three weeks to several months depending on environmental factors such as temperature, moisture, and availability of a suitable host [29]. The infective second stage juveniles (J2) penetrate the roots of the host plant using the piercing action of their stylets. Once inside, the nematode releases esophageal secretions which induce the formation of a multinucleate feeding cell. The J2 becomes sedentary, feeds, and undergoes three molts (J3, J4, adult). Occasionally vermiform males develop and migrate out of the roots, while females remain sedentary, feeding and producing eggs in a gelatinous matrix. Embryogenesis begins inside the egg, and $\mathrm{J}_{2}$ individuals hatch after the first molt [30].

In this work, we demonstrate that overexpression of the Arabidopsis gene AtPAD4 in transgenic soybean roots of composite plants can confer resistance to both SCN and RKN.

\section{Results}

\section{Agrobacterium transformation of soybean roots with red} fluorescent protein (RFP)

The RFP gene was cloned into the pRAP15 vector and expressed in soybean roots to confirm the overexpression functionality of the pRAP15 vector (Figure 1). Transformed roots were identified by the presence of green fluorescent protein (eGFP) throughout the root (Figure 1A). Strong red fluorescence demonstrated that the figwort mosaic virus subgenomic transcript (FMV) promoter was successful in expressing the RFP gene in the transformed soybean roots. Strong green fluorescence throughout the root demonstrated that the rolD promoter was successful for driving the $e G F P$ gene (Figure $1 \mathrm{~B}$ ). When the images were overlapped, the red and green fluorescence were co-localized (Figure 1C). The magnification was 25X.

\section{Agrobacterium transformation of soybean roots with AtPAD4}

We cloned the Arabidopsis PAD4 (AtPAD4) gene into pRAP15 for overexpression in transgenic soybean roots of composite plants. The amino acid sequence of AtPAD4 (AT3G52430) is moderately conserved with the closest soybean homolog Glyma08g00420.2 (Figure 2). AtPAD4 (AT3G52430.1) shares $41.8 \%$ amino acids identity with GmPAD4 (Glyma08g00420.2). Both proteins possess a lipase 3 motif conserved throughout numerous proteins.

Of 100 soybean plants subjected to root transformation with the AtPAD4 gene, 55\% showed evidence of 

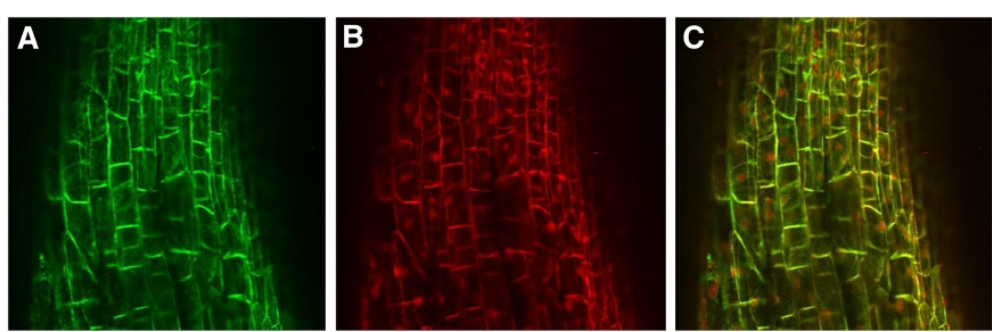

Figure 1 Confirmation of the effectiveness of the plant overexpression vector pRAP15. A, eGFP [green fluorescence], B, RFP [red fluorescence], and C, RFP and eGFP together; magnification 25X.

transformation 28 days after planting as shown by eGFP fluorescence. The transformation efficiency for the empty pRAP15 control plants was $74 \%$. After partial trimming of the untransformed roots and an additional 14 days of growth, all untransformed roots were removed and the remaining roots displaying strong eGFP fluorescence were inoculated with RKN or SCN for assay.

\section{Molecular analysis of putative transgenic plants}

The insertion of the AtPAD4 gene fragments in transgenic soybean plants was detected by PCR (Figure 3) using gene specific primers (Table 1). The $1626 \mathrm{bp}$ fragment was amplified with the gene specific primers. Four plants were tested and all were shown to contain transgenic DNAs. No amplification was detected in untransformed

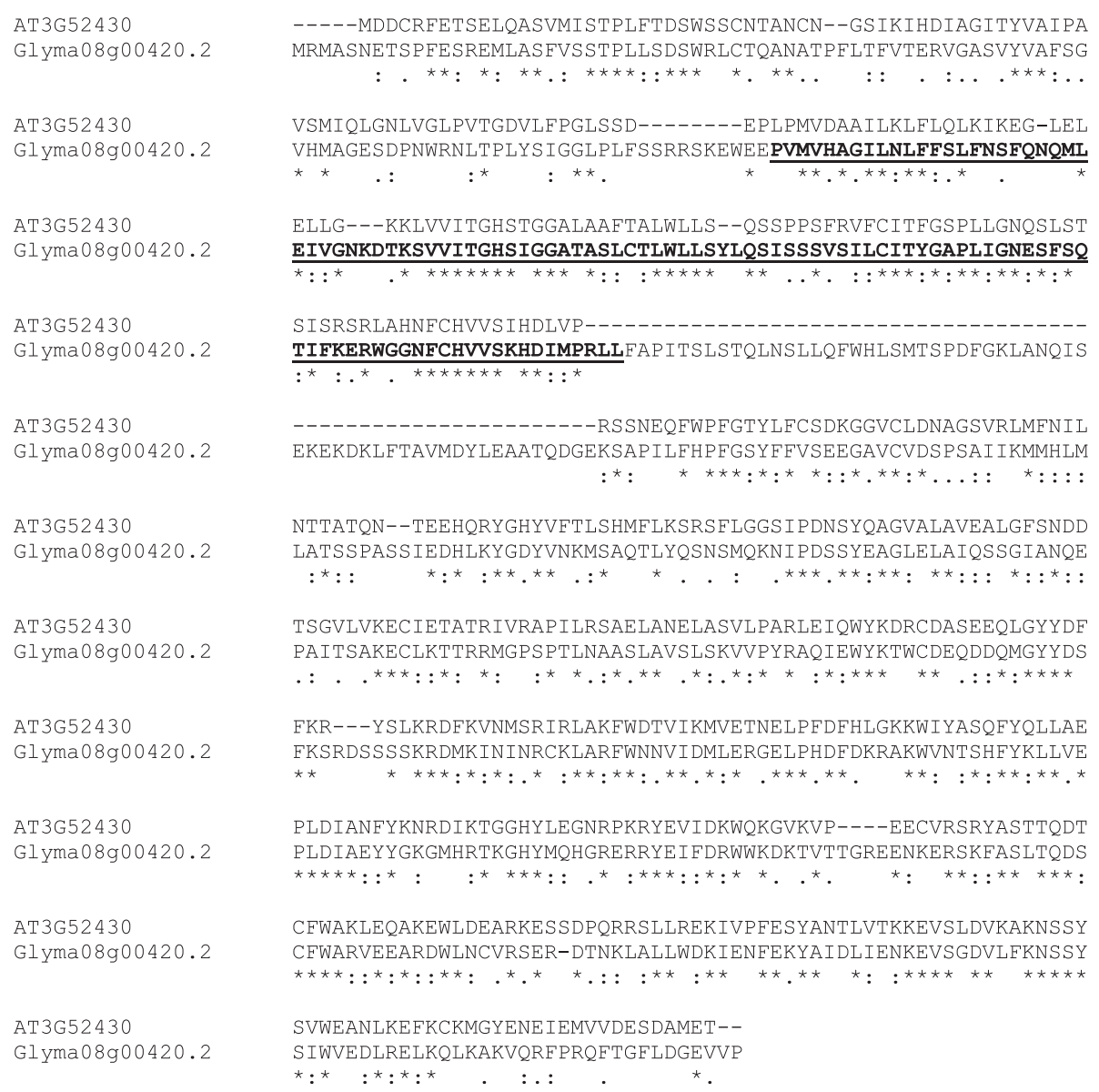

Figure 2 Protein sequence alignment of the coding region of the PAD4 gene from Arabidopis and soybean. ${ }^{*}$, identical amino acid residues aligning in both sequences, :, different but highly conserved (very similar) amino acids aligning in both sequences, ., different amino acids that are somewhat similar aligning in both sequences, -, this column of the alignment contains dissimilar amino acids or gaps, Bold, underlined letters identify the lipase 3 motif. 


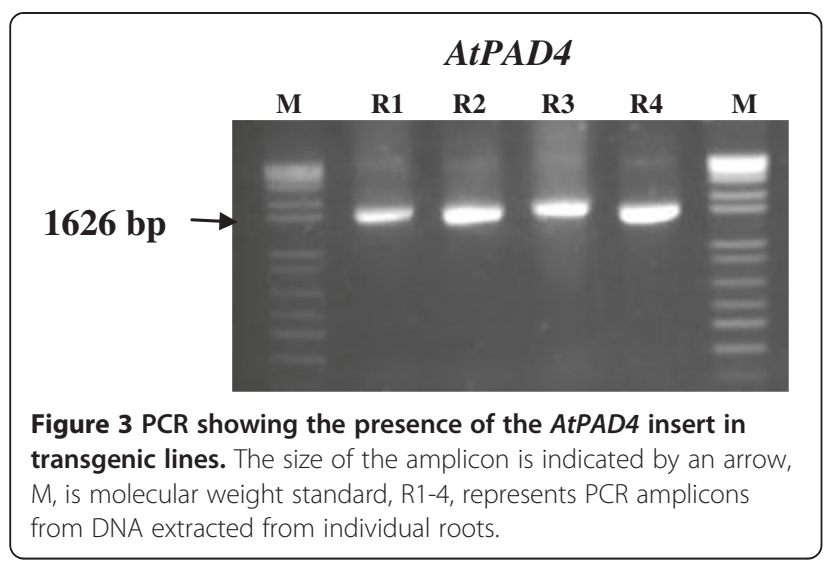

control roots and control roots transformed with empty pRAP15.

qRT-PCR to determine the expression of AtPAD4 gene in soybean roots

Roots expressing eGFP were further analyzed to determine the abundance of AtPAD4 gene transcripts by qRT-PCR using gene specific primers (Table 2). The absolute quantification of the transcripts (number of target molecules) was calculated using the sigmoidal method described by [31]. AtPAD4 transcripts in the overexpressing roots were abundant, while the control roots displayed no detectable to the AtPAD4 (Figure 4A). The number of transcripts of AtPAD4 in the roots transformed with the AtPAD4 construct was calculated to be 24030 molecules. Although transcripts of AtPAD4 were not detectable in the control roots containing empty vector (Figure $4 \mathrm{~B}$ ), transcripts of the housekeeping gene encoding ubiquitin-3 were similar in all samples (Figure 4C).

In addition to measuring transcript levels of AtPAD4, we also used qRT-PCR to determine the number of transcripts of three defense-related genes, GmPAD4; GmEDS1 and GmPR1 (Figure 5). The number of transcripts of GmPAD4 in roots overexpressing AtPAD4 were almost double the number found in control roots. In the same roots, the number of transcripts of GmEDS1 did not change

Table 1 Primers used in PCR amplification and sequencing

\begin{tabular}{|c|c|}
\hline Name & Sequences [5'-3'] \\
\hline AtPAD4-F & CACCAGCCAAGAAGATACATA \\
\hline AtPAD4-R & TTC GAT TTG CTA TTA GTC CTA \\
\hline FMV-F & GGAGCCCTCCAGCTTCAAAG \\
\hline eGFP-F & ATCGATGAATTTGTTCGTGAACTATTAGTTGCGG \\
\hline eGFP-R & ATCGATGCATGCCTGCAGGTCACTGGATITTG \\
\hline$R F P-F$ & CACCTGATGGCCTCCTCCGAG \\
\hline RFP-R & TTAGGCGGTGGAGTG G \\
\hline
\end{tabular}

Table 2 Primers used in qRT-PCR amplification and sequencing

\begin{tabular}{ll}
\hline Name & Sequences [5'-3'] \\
\hline AtPAD4-F & CACCAGCCAAGAAGATACATA \\
AtPAD4-R & TTCGATTGCTATTAGTCCTA \\
Ubiquitin-3-F & GTGTAATGTTGATGTGTTCCC \\
Ubiquitin-3-R & ACACAATTGAGTTCAACACAAACCG \\
GmPR1-F & GCATCATGAATTAGCCAACG \\
GmPR1- $\boldsymbol{R}$ & TTCCAGGTACCAAGCAAGT \\
GmPAD4-F & GGGAAGGGATGCACACAACCAAGG \\
GmPAD4- $\boldsymbol{R}$ & GTTGCCATTCCATCCTTCCACCACCT \\
GmEDS1-F & CGTGAAGAGGCTTGGCTAGCAGGGGTATG \\
GmEDS1- $\boldsymbol{R}$ & CAATGTCTAGAGGCTCCACAAGGCGGCG \\
\hline
\end{tabular}

significantly between AtPAD4-overexpressing roots and control roots. However, the number of transcripts of GmPR1 in AtPAD4-overexpressing roots was almost double that found in control roots containing empty vector.

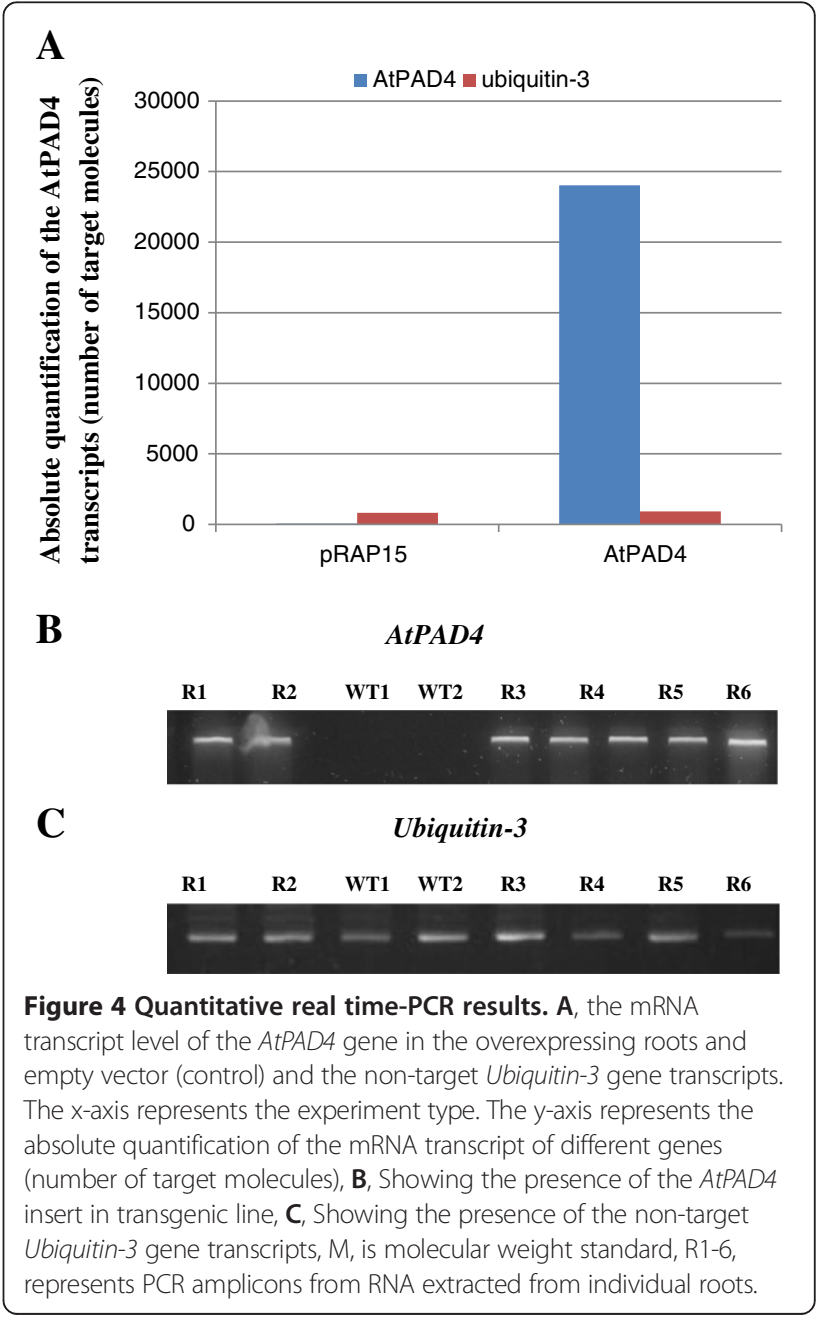




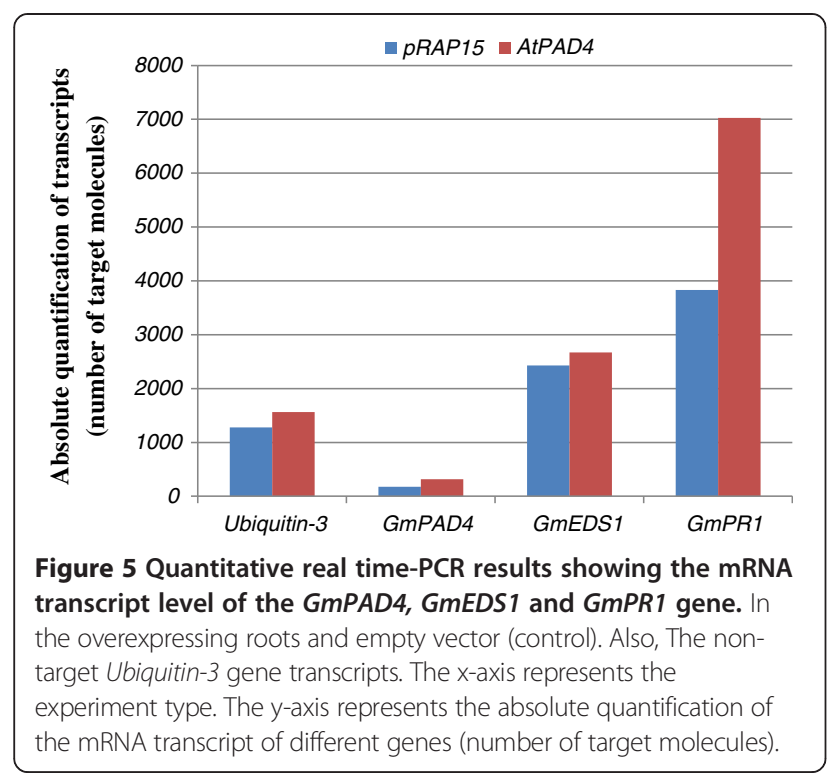

Effect of AtPAD4 overexpression in soybean roots resistance

\section{Resistance to soybean cyst nematode}

The effect of overexpression of AtPAD4 in roots of the susceptible soybean cultivar 'Williams82' on the development of SCN females was examined by counting the number of mature SCN females on AtPAD4-overexpressing and control roots 35 days after inoculation (dai) (Figure 6). There was a $68 \%$ reduction in the mean number of SCN females per plant on AtPAD4-overexpressing roots as compared to the pRAP15 control (Figure 7). When expressed as number of SCN females per gram of root wet weight, the reduction was $76 \%$ in the AtPAD4overexpressing plants. These differences are considered to be statistically significant $(P<0.0001)$, indicating that the

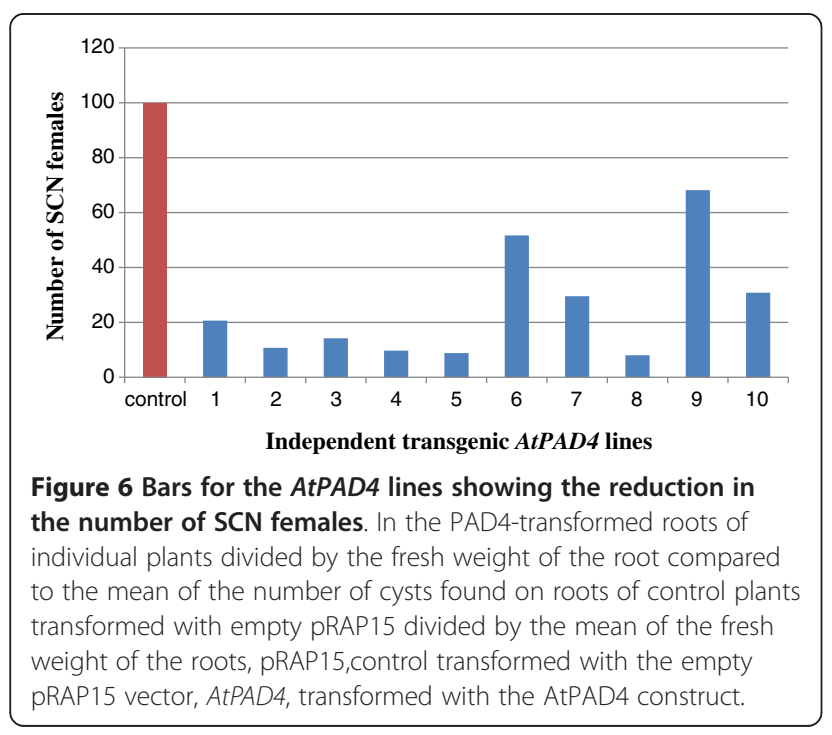

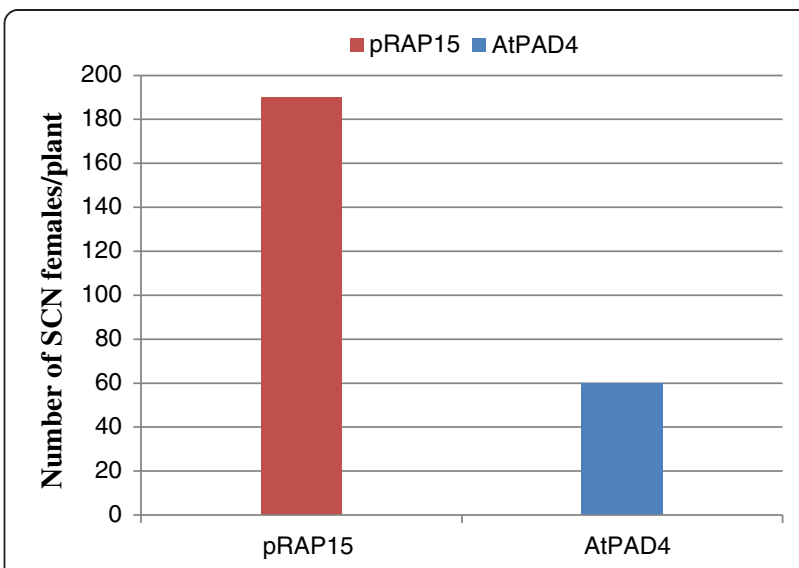

Figure 7 Bars represent the mean number of mature SCN females per plant. PRAP15, control transformed with the empty pRAP15 vector, AtPAD4, transformed with the AtPAD4 constructs.

expression of AtPAD4 in soybean roots interrupted the development of SCN females (Table 3).

\section{Resistance to root knot nematode}

The effect of overexpression of AtPAD4 in roots of the susceptible soybean cultivar 'Williams82' on the development of RKN galls was examined by counting the number of galls on AtPAD4-overexpressing and control roots 35 dai (Figure 8). Under blue light, galls were easily identified as solid, thick green regions on the transformed roots. The mean number of RKN galls per plant was $77 \%$ lower on AtPAD4-overexpressing plants, compared to the pRAP15 control (Figure 9). When expressed as number of RKN galls per gram of root wet weight, the reduction was $72 \%$ in the AtPAD4-overexpressing plants. These differences are considered extremely statistically significant $(\mathrm{P}<0.0001)$ and indicate that the AtPAD4 gene interrupted RKN development (Table 4).

The size of RKN galls and of RKN nematodes within roots was determined 35 dai by measuring the area of their profiles using the Leica Microsystem software version 5.0 for the laser capture microscope. The profile area of RKN galls in roots transformed with AtPAD4 was $86 \%$ smaller than that of RKN galls on control roots

Table 3 Number of mature SCN females collected 35 dai from roots overexpressing AtPAD4 and from control roots

\begin{tabular}{lccc}
\hline Treatment & $\begin{array}{c}\text { No. of } \\
\text { females/ plant }\end{array}$ & $\begin{array}{c}\text { Root wet } \\
\text { weight [g] }\end{array}$ & $\begin{array}{c}\text { No. of females/ } \\
\text { g root wet weight }\end{array}$ \\
\hline NC & $178 \pm 77$ & $5.1 \pm 1.4$ & $35 \pm 19$ \\
pRAP15 & $190 \pm 60$ & $7.3 \pm 1.6$ & $26 \pm 6.9$ \\
AtPAD4 & $60 \pm 41$ & $9.5 \pm 3.5$ & $6.3 \pm 5.3$ \\
\hline
\end{tabular}

Mean \pm standard deviation $[\mathrm{N}=10]$.

$\mathrm{NC}=$ nontransformed control; pRAP15 = empty pRAP15 control. 


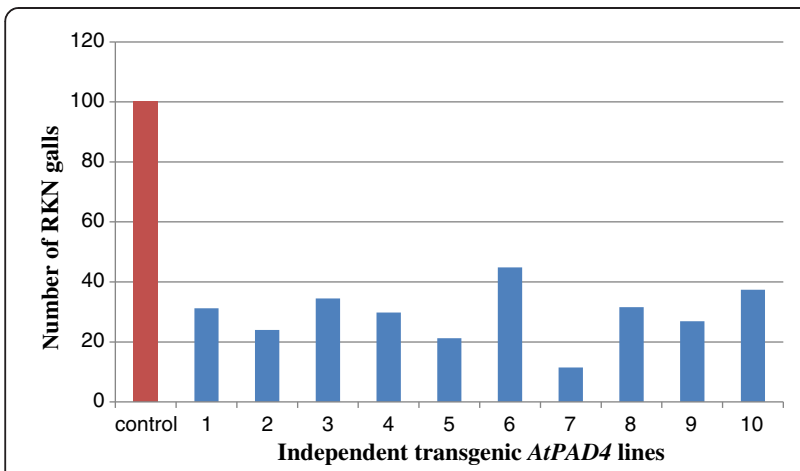

Figure 8 Bars for the AtPAD4 lines showing the reduction in the number of RKN galls. In the PAD4-transformed roots of individual plants divided by the fresh weight of the root compared to the mean of the number of cysts found on roots of control plants transformed with empty pRAP15 divided by the mean of the fresh weight of the roots. PRAP15, control transformed with the empty pRAP15 vector, AtPAD4, transformed with the AtPAD4 constructs.

(Table 5). Similarly, the profile area of RKN nematodes was $66 \%$ smaller in AtPAD4 roots. Thus there were many more immature nematodes in AtPAD4 roots than in control roots. We also observed fewer egg masses on the AtPAD4 roots.

\section{Discussion}

\section{Plant pathogen interaction}

Sedentary endoparasitic nematodes comprise a large group of plant pathogens that infect and parasitize the roots of their hosts. The interaction between these nematodes and their hosts is highly complex, and their obligate root-parasitic nature has proven to be a hindrance to the molecular characterization of these pathosystems, including the targeted exploration of plant defense responses during nematode parasitism. As a consequence, compared with foliar bacterial, viral, and fungal pathogens, there is a

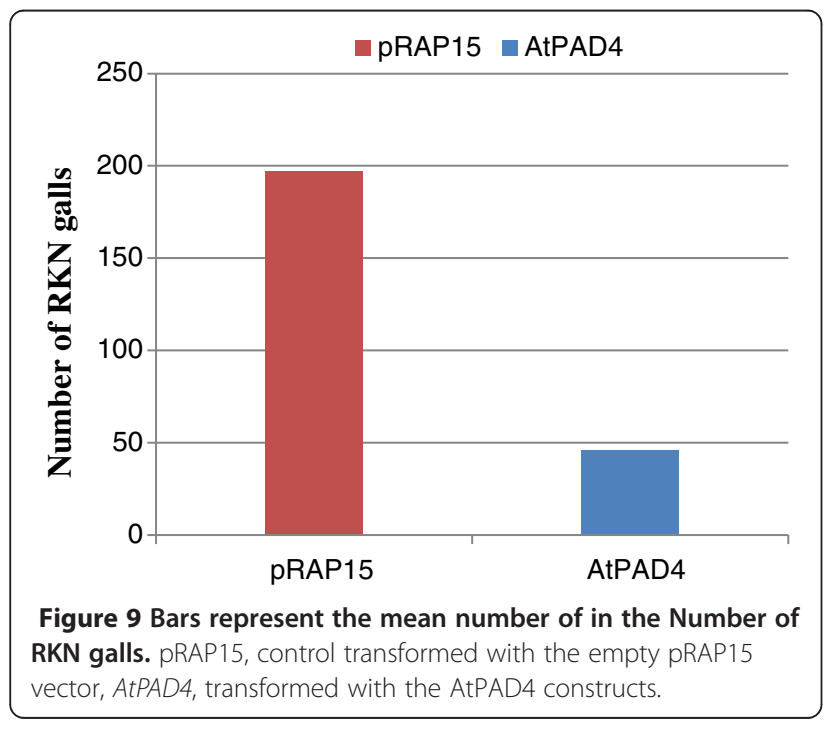

Table 4 Number of RKN galls counted 35 dai on roots overexpressing AtPAD4 and on control roots

\begin{tabular}{lccc}
\hline Treatment & $\begin{array}{c}\text { No. of galls/ } \\
\text { plant }\end{array}$ & $\begin{array}{c}\text { root wet } \\
\text { weight [g] }\end{array}$ & $\begin{array}{c}\text { No. of galls/ g root wet } \\
\text { weight }\end{array}$ \\
\hline NC & $173 \pm 63$ & $8.0 \pm 3.8$ & $22 \pm 10$ \\
pRAP15 & $198 \pm 51$ & $8.1 \pm 1.8$ & $24 \pm 3.1$ \\
AtPAD4 & $46 \pm 18$ & $6.6 \pm 2.2$ & $6.9 \pm 2.2$ \\
\hline
\end{tabular}

Mean \pm standard deviation $[\mathrm{N}=10]$.

NC = nontransformed control; pRAP15 = empty pRAP15 control.

considerable lack of knowledge regarding which defense signaling genes or pathways are effective against plantparasitic nematodes during a compatible interaction.

Effective plant defense against pests and pathogens involves recognition and activation of appropriate defenses. Similar underlying mechanisms are likely to control this fundamental process in all flowering plants [32]. Therefore, structural and functional analysis of genes involved in plant defense in a model species such as Arabidopsis thaliana (L.) Heynh, can facilitate the identification of structural and functional orthologs and their role in disease resistance pathways in other plant species $[1,8]$.

Natural plant populations and breeding populations of crop plants show qualitative and quantitative phenotypic variation for resistance to pests and pathogens. Qualitative resistance is characterized by two distinct phenotype classes, resistant and susceptible, and follows Mendelian inheritance. It is this type of single gene- or resistance (R) gene-mediated resistance that has been most thoroughly studied in the context of plant-pathogen recognition and defense signaling [33-36]. In contrast, quantitative resistance is characterized by continuous phenotypic variation ranging from high susceptibility to high resistance among the recombinant individuals within a progeny. Such resistance is controlled by more than one gene and can be strongly influenced by environmental factors. Resistance to $\mathrm{SCN}$ is controlled by several resistance ( $R h g$, resistance to Heterodera glycines) genes [37-40], and soybean cultivars can display a range of reactions to $\mathrm{SCN}$ encompassing highly susceptible to resistant depending upon the SCN population used for testing and the complement of $R h g$ genes within the genome of the cultivar. The resistance genes appear to work in a SCN population-specific or race-specific manner and most contribute only a small, additive amount to resistance $[37,38]$.

Table 5 Size of RKN galls and immature females as measured by the areas of their profiles

\begin{tabular}{lcc}
\hline Treatment & Gall profile area $\left[\mathrm{mm}^{2}\right]$ & Nematode profile area $\left[\mathrm{mm}^{2}\right]$ \\
\hline pRAP15 & $1.57 \pm 0.63$ & $0.083 \pm 0.03$ \\
AtPAD4 & $0.23 \pm 0.15$ & $0.028 \pm 0.007$ \\
\hline
\end{tabular}

Mean \pm standard deviation $[\mathrm{N}=10]$.

pRAP15 = empty pRAP15 control. 


\section{Arabidopsis-pathogen interactions}

The genetic dissection of Arabidopsis-pathogen interactions revealed great insights into plant defense and various defense signaling pathways. Our knowledge of $R$ geneactivated defenses, as well as regulators of salicylic acid (SA), jasmonic acid (JA), and ethylene (ET) dependent response pathways has expanded greatly in the last two decades [33,41]. Analyses of $A$. thaliana mutants that perturb various aspects of SA-mediated signal transduction has revealed that $\mathrm{SA}$ is an inhibitor of cyst nematode parasitism during a compatible interaction [42]. Mutants unable to synthesize or accumulate SA (sid2-1, pad4-1, and nahG) showed a consistently increased susceptibility phenotype to H. schachtii. The pretreatment of wild-type plants with SA significantly decreased their susceptibility to the nematode while simultaneously inducing PR-1 gene expression in both roots and shoots. Taken together, these data strongly suggest that SA mediated signaling plays a significant role in limiting nematode parasitism during a compatible interaction. [43] showed that application of SA to tomato plants prior to inoculation with root-knot nematode alleviated root galling; however, this effect of SA was believed to be nematicidal in nature due to the high concentrations of SA that were used in the experiment. [10,44] showed that PAD4 modulates camalexin synthesis and SA synthesis and signaling in Arabidopsis defense against pathogens.

Although, there have been extensive studies on the defense response of Arabidopsis to fungal and bacterial pathogens (1-6), little of this work in Arabidopsis has been directly translated to economically important food crops, such as soybean, and particularly in respect to plant parasitic nematodes. The Arabidopsis lipase-like protein PHYTOALEXIN DEFICIENT4 (PAD4) was identified by several genetic studies as essential component for plant immunity against virulent pathogens for promoting the defense signaling hormone salicylic acid (SA) and the phytoalexin camalexin [8-10,33]. Our experiments show that AtPAD4can be used in an economically important crop, soybean, to provide a measure of resistance to two different genera of nematodes. In Arabidopsis, the PAD4 gene functions upstream of the defense responses triggered by SA [45]. PAD4 can work in combination with EDS1 to trigger aspects of the defense response, but EDS1 can also interact with SAG101 independent of PAD4 [45]. In our experiments, overexpression of AtPAD4 in soybean roots did not greatly influence levels of transcripts of GmEDS1, but there was an increase in Gm PR1 transcripts. PR1 transcription is responsive to increased SA levels and is downstream of SA [46-48]. Overexpression expression of AtPAD4 in transgenic Arabidopsis conferred resistance to green peach aphid [49]. This resistance did not require EDS1. Our data, extend understanding of AtPAD4 by showing that this Arabidopsis gene can be overexpressed in an economically important crop to confer resistance to two distinct genera of nematodes.

\section{Conclusions}

Here, we demonstrated that the overexpression of AtPAD4 in roots of G. max confers resistance to two different genera of nematodes. It decreases the number of mature female SCN cysts and decreased the number of galls formed by RKN in the susceptible soybean cultivar 'Williams82'. Moreover, the size of RKN galls and nematodes in AtPAD4-expressing roots was significantly reduced and fewer egg masses were present, confirming that the ectopic overexpression AtPAD4 in soybean roots disrupted the RKN life cycle. This work provides a basis for unraveling the potential role of defense signaling genes in quantitative disease resistance in this major crop species, and it demonstrates that an Arabidopsis gene can confer resistance in an important field crop to two genera of nematodes having worldwide importance.

\section{Methods}

Nematode procurement

SCN (H. glycines) females were harvested from soybean (G. $\max$ ) roots 2-4 months after inoculation. The females were purified by sucrose flotation and then crushed gently to release the eggs. The eggs were sterilized by 0.5 percent sodium hypochlorite solution for $1.5 \mathrm{~min}$ then washed with sterile water and placed in a small plastic tray with $120 \mathrm{~mL}$ sterile water and $1.2 \mathrm{~mL}$ sterile $300 \mathrm{mM}$ $\mathrm{ZnSO} 4.7 \mathrm{H} 2 \mathrm{O}$. The tray was placed on a heated shaker at $28^{\circ} \mathrm{C}$ and $50-75 \mathrm{rpm}$ for aeration. After 2 days, the J2s were separated from unhatched eggs and concentrated to a final optimized concentration of $1,000 \mathrm{~J} 2 \mathrm{~mL}^{-1}$. Two milliliters of $\mathrm{J} 2$ inoculum were added to each root system. RKN (M. incognita) females were harvested from roots of peppers (Capsicum annuum) cultivar PA136 2-4 months after inoculation. Eggs used to inoculate roots of soybean seedlings (Glycine max, cv. Williams 82) were extracted using a $1 \% \mathrm{NaOCl}$ solution [44]. The concentration of the egg suspension was adjusted to 1500 eggs $\mathrm{mL}^{-1}$. Two milliliters of inoculum were added to each root system. The plants were then grown in the greenhouse for 35 days, for both the SCN and RKN experiments. Confirmation of infection in representative infected root samples was performed by the acid fuchsin staining procedure of [50].

\section{Isolation of PAD4 homolog from Arabidopsis thaliana First strand CDNA synthesis}

Total RNA was extracted from Arabidopsis thaliana leaves using the RNeasy Mini Kit (Qiagen, USA) and used to synthesize first-strand cDNA using the SuperScript III First-Strand Synthesis System for RT-PCR (Invitrogen, Carlsbad, CA)with oligo $\mathrm{d}(\mathrm{T})$ as primer according to the manufacturer's instructions. 


\section{Amplification and purification of AtPAD4 CDNA}

The Arabidopsis PAD4 gene (accession No. NM_115103) was amplified from cDNA from $A$. thaliana leaves using gene specific primers (Table 4) to yield a 1626-bp product. We added a CACC sequence to the $5^{\prime}$ end of forward primer to enable insertion of the amplicon into the pENTR vector (Invitrogen). The PCR product was purified using the E-Gel ${ }^{\oplus}$ Electrophoresis System (Invitrogen).

\section{Gene cloning}

The pENTR ${ }^{\mathrm{rm}}$ Directional TOPO Cloning Kit (Invitrogen, Carlsbad, CA) was used to clone AtPAD4 into the pENTR cloning vector. The resulting construct was transformed into competent Escherichia coli cells using One Shot Mach1 ${ }^{\mathrm{TM}}$ T1R chemically competent E. coli (Invitrogen, Carlsbad, CA), and the plasmid was harvested using the QIAprep Spin Miniprep Kit (Qiagen, Valencia, CA). Presence and orientation of AtPAD4 were confirmed by DNA sequencing the positive samples using a 3130XL Genetic Analyzer (Applied Biosystems, Foster City, CA). AtPAD4 was moved from the pENTR vector to the plant overexpression vector pRAP15 (Figure 1) using Invitrogen's Gateway technology. The pRAP15 vector has a tetracycline resistance gene (TetR)for bacterial selection engineered into a BstEII site that lies outside the left and right borders and the enhanced green fluorescent protein $(e G F P)$ gene [51]driven by the rolD root promoter [52,53]for visual screening of transformed roots [51]. The inserted AtPAD4 gene was driven by the figwort mosaic virus subgenomic transcript (FMV-sgt) promoter [51], which exhibits strong, constitutive root expression. The cloning reaction was mediated by the Gateway LR Clonase ${ }^{\mathrm{Tm}}$ II Enzyme Mix (Invitrogen,Carlsbad, CA)and involves crossing over between attR sites on pRAP15 and attL sites on pENTR, with AtPAD4 replacing the lethal $c c d \mathrm{~B}$ gene that is used for bacterial selection. Colony PCR was used to confirm the presence and/or orientation of AtPAD4 and eGFP using the following primers sets: (1) FMV-F + PAD4-R; (2) $e G F P-F+e G F P-R$ (Table 4).

\section{Agrobacterium transformation}

The pRAP15 clone was moved into competent Agrobacterium rhizogenes $\mathrm{K} 599$ following the procedure of [54]. Plates were grown for 3 days at $30^{\circ} \mathrm{C}$, and colonies were transferred to tubes of $5 \mathrm{~mL}$ TB liquid media containing $5 \mathrm{mg} \mathrm{mL}^{-1}$ tetracycline and incubated overnight at $37^{\circ} \mathrm{C}$. Transformations were confirmed by PCR as described above.

\section{Plant transformation and challenge with $M$. incognita and H. glycines}

A culture of $A$. rhizogenes transformed with either the empty pRAP15 control or pRAP15+ RFP and pRAP15 $+A t P A D 4$ genes was grown in $5 \mathrm{~mL}$ TB liquid medium containing $5 \mathrm{mg} \mathrm{mL}^{-1}$ tetracycline overnight at room temperature on a rotary shaker at $250 \mathrm{rpm}$. The $5-\mathrm{mL}$ culture was used to inoculate $600 \mathrm{~mL}$ of the same medium and then incubated under the same conditions. The culture was centrifuged at $5000 \mathrm{rpm}$ at $4^{\circ} \mathrm{C}$ for 30 min. The pellet was resuspended in Murashige and Skoog medium (MS) with 3\% sucrose. One hundred plants of a soybean cultivar (G. $\max$ cv. 'William 82') susceptible to parasitism by $\mathrm{SCN}$ and $\mathrm{RKN}$ were grown for each experiment for 9 days before transformation. Composite plants with roots transformed by $A$. rhizogenes were produced following the method of [51]. In brief, shoots were cut at the soil line, placed in the a suspension of $A$. rhizogenes in MS medium, vacuum infiltrated for $30 \mathrm{~min}$, then incubated overnight at $23^{\circ} \mathrm{C}$ at $65 \mathrm{rpm}$ in a were planted in 50-cell flats filled with prewetted Promix. MS medium inoculated with the same amount of water instead of the transformed $A$. rhizogenes culture was used in a mock transformation to produce non-transformed control (NC) plants. After incubation, the stems were rinsed with water, placed in a beaker of water, and incubated for approximately $48 \mathrm{hr}$ at $23{ }^{0} \mathrm{C}$ in a growth chamber. The plantlets were planted in pre-wetted Promix in the greenhouse. Four weeks after planting, the plants were screened to identify transformed roots using a Dark Reader Spot lamp (Clare Chemical Research, Dolores, CO).

For each experiment, 33 plants with the healthiest roots and strongest eGFP expression were selected 28 days after planting, and nontransformed roots were partially removed. The plants were replanted in soil and grown for an additional 14 days, after which 10 plants were selected for nematode assay, and all nontransformed roots were removed. Roots were challenged with 2000 H. glycines J2 per plant or 3000 M. incognita eggs per plant. Inocula were pipetted into 2 holes in the soil near the plant stem and about one inch deep. Ten plants were used for each experiment. Mature SCN females and RKN galls were counted 35 days after plant inoculation (dai).

\section{RKN galls counts and measurements}

Thirty five days after inoculation with RKN, ten plants were uprooted. The roots were washed free of soil and fresh weights were recorded. RKN galls were counted. The sizes of ten RKN galls and the sizes of ten RKN nematodes within roots were determined by cutting the roots into 1 to 2-cm-pieces and staining with acid fuchsin according to [50]. Galls were placed on slides containing a drop of glycerol. No coverslip was used. The area of each gall and RKN was determined by circumscribing the profile of each using the laser capture microscope Leica Microsystem platform and software version 5.0. The same magnification was used for all samples. 


\section{SCN female counts}

Mature SCN females were collected from individual plants over nested 20- and 60-mesh sieves. Collected females in $\sim 30 \mathrm{~mL}$ of water were washed into $150 \mathrm{ml}$ beakers. The females were poured onto 9-cm diameter filter paper (Schleicher and Schuell; Keene, NH) in a Buchner funnel system under constant vacuum. Counting was done under a dissecting microscope. Both the RKN and $\mathrm{SCN}$ experiments were analyzed by $t$-test using the GraphPad software (La Jolla, CA).

\section{Confirmation of the effectiveness of the plant overexpression vector}

The functionality of the plant overexpression vector pRAP15 was confirmed by using it to overexpress a red fluorescent protein (RFP) in soybean roots. The pRAP15 + RFP construct was cloned as described above at USDAARS, Soybean Genomic and Improvement Laboratory, Beltsville, MD, USA, using the primers RFP-F and RFP-R (Table 1). The vector, pRAP15 contains the figwort mosaic virus subgenomic transcript (FMV-sgt) promoter driving the expression of the tandem inverted repeat cassette. This promoter exhibits strong, constitutive root expression throughout the entire course of $H$. glycines infection. Images of roots expression of eGFP and RFP were obtained using a Zeiss 710 Laser Scanning Confocal Microscope (LSCM) and a Zeiss Axio Observer ${ }^{\mathrm{TM}}$ inverted microscope with a 40x1.2 NA water immersion plan apochromatic objective. An Argon laser was used to excite eGFP at $488 \mathrm{~nm}$ and emission was monitored between 500 to $510 \mathrm{~nm}$ with a MBS 488/561/633 filter set. RFP was excited at $561 \mathrm{~nm}$ with a diode pumped solid state laser and the emission detected at 575 to $620 \mathrm{~nm}$ with the 488/561/633 filter set. Zeiss ZenTM 2009 was used to capture the images and Axiophot $4.6^{\mathrm{mM}}$ and Photoshop $7.0^{\mathrm{TM}}$ were utilized to design the figures.

\section{Molecular analysis of putative transgenic plants}

Genomic DNA isolated from roots of healthiest transgenic roots that displaying the strongest eGFP fluorescence and control soybean plants using a DNeasy plant mini kit (Qiagen, USA). The presence of the AtPAD4. gene in the transgenic roots was confirmed by PCR.

Sequence specific primers (Table 1) were used for amplification the AtPAD4 DNA fragment using plant genomic DNA as template. DNA extracted from untransformed plants was used as negative control. Also, primers amplifying fragments of approximately $132 \mathrm{bp}$ from the soybean ubiquitin-3 gene, GenBank accession D28123, were used to confirm that soybean DNA was present in all samples. The PCR conditions included initial melting temperature of $94^{\circ} \mathrm{C}$ for $2 \mathrm{~min}$ followed by 35 cycles of $94^{\circ} \mathrm{C}$ for $30 \mathrm{~s}, 65^{\circ} \mathrm{C}$ for $30 \mathrm{~s}$ and $72^{\circ} \mathrm{C}$ for 2 min. This was followed by a final extension time of 10 min at $72^{\circ} \mathrm{C}$. The PCR mixture included $0.4 \mu \mathrm{l}$ Taq polymerase (Invitrogen, Carlsbad, CA, USA), $50 \mathrm{mM} \mathrm{Mgcl} 2$ and $10 \mathrm{mM}$ dNTPs. The template plasmid DNA concentration was $1-10 \mathrm{ng} \mu^{-1}$. The amplified PCR fragments were resolved on a $0.8 \mathrm{~g} / \mathrm{ml}$ agarose gel and observed under ultraviolet light.

\section{Quantitative real-time reverse transcription polymerase chain reaction (qRT-PCR) to determine the transcript level of AtPAD4 and defense genes inside plant roots}

RNA was extracted from three individual roots $(100 \mathrm{mg}$ each), roots transformed with the empty pRAP15 (as a control) having the strongest eGFP expression and representing independent transformation events using the Ultra Clean Plant RNA Isolation Kit (MOBIO, Carlsbad, CA). The RNA was treated with DNase I to remove genomic DNA. The RNA was utilized to synthesize single-stranded cDNA using reverse transcriptase (Invitrogen, Carlsbad, CA) and oligo dT primers, according to the manufacturer's instructions. All the primer sets were designed to flank a region that contains one intron to make sure that the expected size product was amplified from cDNA and not from genomic DNA. Primers (Table 2) were designed to be specific to the flanking region of the Arabidopsis PAD4 (AtPAD4) and to yield PCR-amplified fragments of approximately 150 bp. Also, the soybean ubiquitin-3 gene, GenBank accession D28123 used as a positive RT-PCR control for the experiment to confirm that the soybean RNA was present in all samples. And the soybean genes (GmPAD4; GmEDS1) Phytozome accession Glyma06g16290.1; Glyma06g19920.1 and (GmPR1) GenBank accession XM_003545723.1as related defense genes.

Other controls for qRT-PCR included reactions containing no template and $\mathrm{qRT}-\mathrm{PCR}$ reactions containing no reverse transcriptase. qRT-PCR was performed on three biological replicates and each reaction was replicated three times. Relative quantities of gene expression were determined using the Stratagene Mx3000P Real-Time PCR system (Stratagene, La Jolla, CA) as described by the manufacturer. DNA accumulation during thereaction was measured with SYBR Green. The Ct (cycle at which there is the first clearly detectable increases in fluorescence) values were calculated using software supplied with the Stratagene Mx3000P Real-Time PCR system. SYBR green dissociation curve of amplified products demonstrated the production of only one product per reaction. Data analysis was performed according to the sigmoidal model described by [31] to get absolute quantification. The PCR products were run on $0.8 \%$ agarose gel and visualized under UV light.

Authors' contributions

BM carried out the design of the experiments, designed the overexpression vector, helped to draft the manuscript and performed the statistical analysis. RY carried out the molecular genetics and nematodes studies,

transformation, performed the statistical analysis and drafted the manuscript. 
KK participated in the design and construction of the overexpression vector. MM participated in the nematodes. EB participated in the statistical analysis and helped to draft the manuscript. GB conducted the Laser Scanning Confocal Microscope studies. All authors read and approved the final manuscript.

\section{Acknowledgements}

The authors thank Susan Meyer, Ann Smigocki and Hua Lu for critical reading of the manuscript. DNA sequencing was performed by the Peter Van Berkum Laboratory, USDA-ARS Soybean Genomics \& Improvement Laboratory. Financial support from United Soybean Board no.1292 is gratefully acknowledged. Mention of trade names or commercial products in this publication is solely for the purpose of providing specific information and does not imply recommendation or endorsement by the U.S. Department of Agriculture. The U.S. Department of Agriculture (USDA) prohibits discrimination in all its programs and activities on the basis of race, color, national origin, age, disability, and where applicable, sex, marital status, familial status, parental status, religion, sexual orientation, genetic information, political beliefs, reprisal, or because all or part of an individual's income is derived from any public assistance program. (Not all prohibited bases apply to all programs). Persons with disabilities who require alternative means for communication of program information (Braille, large print, audiotape, etc.) should contact USDA's TARGET Center at (202)720-2600 (voice and TDD). To file a complaint of discrimination, write to USDA, Director, Office of Civil Rights, 1400 Independence Avenue, S.W., Washington, D.C. 20250-9410, or call (8000795-3272 (voice)or (202)720-6382 (TDD). USDA is an equal opportunity provider and employer.

\section{Author details}

'USDA-ARS, Soybean Genomic and Improvement Laboratory, 10300 Baltimore Ave, Bldg 006, Beltsville, MD 20705, USA. ${ }^{2}$ Cell and Genetics Division, National Institute of Agricultural Biotechnology, Rural Development Administration, Suwon 441-100, South Korea. ${ }^{3}$ Plant Protection Department, Faculty of Agriculture, Fayoum University, Fayoum, Egypt.

Received: 21 March 2013 Accepted: 22 April 2013

Published: 25 April 2013

\section{References}

1. Hammond-Kosack KE, Jones JDG: Inducible plant defence mechanisms and resistance gene function. Plant Cell 1996, 8:1773-1791.

2. Baker B, Zambryski P, Staskawicz B, Dinesh-Kumar SP: Signaling in plantmicrobe interactions. Science 1997, 276:726-733.

3. Crute I, Beynon J, Dangl J, Holub E, Mauch-Mani B, Slusarenko A, Staskawicz B, Ausubel FE, Meyerowitz M: Microbial pathogenesis of Arabidopsis. In Arabidopsis. Edited by Meyerowitz EM, Somerville CR. Cold Spring Harbor, NY: Cold Spring Harbor Laboratory Press; 1994:705-747.

4. Ryals JA, Neuenschwander UH, Wilits MG, Molina A, Steiner HY, Hunte MD: Systemic acquired resistance. Plant Cell 1998, 8:1809-1819.

5. Gaffney T, Friedrich L, Vernooij B, Negrotto D, Nye G, Uknes S, Ward E, Kessmann $\mathrm{H}$, Ryals J: Requirement of salicylic acid for the induction of systemic acquired resistance. Science 1993, 261:754-756.

6. Delaney TP, Uknes S, Vernooij B, Friedrich L, Weymann K, Negrotto D, Gaffney T, Gut-Rella M, Kessman H, Ward E, Ryals J: A central role of salicylic acid in plant disease resistance. Science 1994, 266:1247-1250.

7. Bartsch M, Gobbato E, Bednarek P, Debey S, Schultze JL, Bautor J, Parker JE: Regulators of salicylic acidindependent EDS1 signaling in Arabidopsis immunity and cell death. Plant Cell 2006, 18:1038-1051.

8. Glazebrook J, Zook M, Mert F, Kagan I, Rogers EE, Crute IR, Houlb EB, Hammerschmidt R, Ausubel FM: Phytoalexin- deficient mutants of Arabidopsis reveal that PAD4 encodes a regulatory factor and that four PAD genes contribute to downy mildew resistance. Genetics 1997, 146:381-392.

9. Jirage D, Tootle TL, Reuber TL, Frost LN, Feys BJ, Parker JE, Ausubel FM, Glazebrook J: Arabidopsis thaliana PAD4 encodes a lipase-like gene that is important for salicylic acid signaling. Proc. Natl Acad. Sci. USA 1999, 96:13583-13588.

10. Zhou N, Tootle TL, Tsui F, Klessig DF, Glazebrook J: PAD4 functions upstream from salicylic acid to control defense responses in Arabidopsis. Plant Cell 1998, 10:1021-1030.

11. Pegadaraju V, Knepper C, Reese JC, Shah J: Premature leaf senescence modulated by the Arabidopsis thaliana PAD4 gene is associated with defense against the phloem feeding green peach aphid. Plant Physiol 2005, 139:1927-1934.

12. Falk A, Feys BJ, Frost LN, Jones JDG, Daniels MJ, Parker JE: EDS1, an essential component of $\mathrm{R}$ gene-mediated disease resistance in Arabidopsis has homology to eukaryotic lipases. Proc. Natl Acad. Sci. USA 1999, 96:3292-3297.

13. Feys BJ, Wiermer M, Bhat RA, Moisan LJ, Medina-Escobar N, Neu C, de CruzCabral A, Parker JE: Arabidopsis Senescence-associated gene101 stabilizes and signals within an enhanced disease susceptibility 1 complex in plant innate immunity. Plant Cell 2005, 17:2601-2613.

14. Feys BJ, Moisan $\amalg$, Newman MA, Parker JE: Direct interaction between the Arabidopsis disease resistance signaling proteins, EDS1 and PAD4. EMBO J 2001, 20:5400-5411.

15. Sasser JN, Freckman DW: A world perspective on nematology: the role of society. Vistas on Nematology 1987:7-14

16. Williamson VA, Gleason CA: Plant nematode interactions. Plant Biol. 2003, 6:327-333

17. Wyss U: Observation on the parasitic behavior of $H$. schachtii throughout its development inside roots. Fundam Appl Nematol 1992, 15:75-89.

18. Williamson VM, Hussey RS: Nematode pathogenesis and resistance in plants. Plant Cell 1996, 8:1735-1745.

19. Wang XH, Meyers D, Yan Y, Baum TJ, Smant G, Hussey RS, Davis EL: In planta localization of a $\beta-1$, 4-endoglucanase secreted by $\mathrm{H}$. glycines. Mol Plant Microbe Interact 1999, 12:64-67.

20. Davis EL, Hussey RS, Baum TJ: Getting to the roots of parasitism by nematodes. Trends Parasitol 2004, 20:134-141.

21. Baum TJ, Hussey RS, Davis EL: Root-knot nematode parasitism genes: the molecular basis of plant parasitism. Genet Eng 2007, 28:17-43.

22. Jones MGK: Host cell responses to endoparasitic nematode attack: structure and function of giant cells and syncytia. Ann Appl Biol 1981, 97:353-372

23. Endo BY: From Histology and ultra structural modification induced by cyst nematodes: Cyst Nematodes. In Edited by Lambert F, Taylor CE. New York: Plenum Press; 1986:133-146.

24. Wyss U, Grundler FMW: Feeding behavior of sedentary plant-parasitic nematodes. Neth. J. Plant Pathol. 1992, 98(Suppl 2):165-173.

25. Gheysen G, Fenoll C: Gene expression in nematode feeding sites. In Annul. Golden AM, Terminology and identity of infraspecific forms of the soybean cyst nematode [H. glycines] 1997; Edited by Epps JM, Riggs RD, Duclos LA, Fox JA, Bernard RL. Plant Dis. Rep 2002, 54:544-546.

26. Jasmer DP, Goverse A, Smant G: Parasitic nematode interactions with mammals and plants. Annu Rev Phytopathol 2003, 41:245-270.

27. Mahalingam R, Skorupska HT: Cytological expression of early response to infection by $\mathrm{H}$. glycines Ichinohe in resistant PI 437654 soybean. Genome 1996, 39:986-998.

28. Hussey RS, Davis EL, Baum TJ: Secrets in secretions: genes that control nematode parasitism in plants. Braz. J. Plant Physiol. 2002, 14:183-194.

29. Taylor AL, Sasser JN: Biology, identification and control of root-knot nematodes [Meloidogyne sp.]. Raleigh, NC, USA: North Carolina: State University Graphics Press; 1978.

30. Abad P, Gouzy J, Aury JM, Castagnone-Sereno P, Danchin EGJ, Deleury E, Perfus-Barbeoch L, Anthouard V, Artiguenave F, Blok VC, Caillaud MC, Coutinho PM, Dasilva C, De Luca F, Deau F, Esquibet M, Flutre T, Goldstone JV, Hamamouch N, Hewezi T, Jaillon O, Jubin C, Leonetti P, Magliano M, Maier TR, Markov GV, McVeigh P, Pesole G, Poulain P, Robinson-Rechavi M, et al: Genome sequence of the metazoan plant-parasitic nematode Meloidogyne incognita. Nature Biotechnology 2008, 26(Suppl 8):909-915.

31. Rutledge RG, Stewart D: A kinetic-based sigmoidal model for the polymerase chain reaction and its application to high-capacity absolute quantitative real-time PCR. BMC Biotechnol 2008, 8:47.

32. McDowell JM, Woffenden BJ: Plant disease resistance genes: recent insights and potential applications. Trends Biotechnol 2003, 21:178-183.

33. Glazebrook J: Genes controlling expression of defense responses in Arabidopsis. Plant Biol. 2001, 4:301-308.

34. Feys BJ, Parker JE: Interplay of signaling pathways in plant disease resistance. Trends Genet 2000, 16:449-455.

35. Hulbert SH, Webb CA, Smith SM, Sun Q: Resistance gene complexes: evolution and utilization. Annu Rev Phytopathol 2001, 39:285-312.

36. Kombrink E, Somssich IE: From Pathogenesis-related proteins and plant defense. In the Plant Relationships. Mycota V, Part A. Edited by Carroll GC, Tudzynski P. Verlag, Berlin: Springer; 1997:107-128. 
37. Concibido VC, Lange DA, Denny RL, Orf JH, Young ND: Genome mattiong of soybean cyst nematode resistance genes in 'Peking', PI 90763, and PI 88788 using DNA markers. Crop Sci 1997, 37:258-264.

38. Concibido VC, Diers BW, Arelli PR: A decade of QTL mapping for cyst nematode resistance in soybean. Crop Sci 2004, 44:1121-1131.

39. Matson AL, Williams LF: Evidence of a fourth gene for resistance to the soybean cyst nematode. Crop Sci 1965, 5:477.

40. Rao-Arelli AP, Anad SC, Wrather JA: Soybean resistance to soybean cyst nematode race 3 is conditioned by and additional dominant gene. Crop Sci 1992, 32:862-864.

41. Glazebrook J: Contrasting mechanisms of defense against biotrophic and necrotrophic pathogens. Annu Rev Phytopathol 2005, 43:9.1-9.23.

42. Wubben MJ, Jin J, Baum TJ: Cyst nematode parasitism of Arabidopsis thaliana is inhibited by salicylic Acid [SA]and elicits uncoupled SAindependent pathogenesis-related gene expression in roots. MPMI 2008, 21:424-443.

43. Maheshwari DK, Anwar M: Nematicidal activity of some phenolics on root knot, growth and yield of Capsicum frutescens cv. California Wonder. J Phytopathol 1990, 129:159-164.

44. Zhou N, Tootle TL, Tsui F, Klessig F, Glazebrooka J: PAD4 Functions upstream from salicylic acid to control defense responses in Arabidopsis. Plant Cell 1998, 10:1021-1030.

45. Rietz S, Stamm A, Malonek S, Wagner S, Becker D, Medina-Escobar N, Vlot CA, Feys BJ, Niefind K, Parker JE: Different roles of Enhanced Disease Susceptibility1 (EDS1) bound to and dissociated from Phytoalexin Deficient4 (PAD4) in Arabidopsis immunity. New Phytol 2011, 191:107-119.

46. Qin XF, Holuige L, Horvath DM, Chua NH: Immediate early transcription activation by salicylic acid via the cauliflower mosaic virus as-1 element. Plant Cell 1994, 6:863-874.

47. Shah J, Tsui F, Klessig DF: Characterization of a salicylic acid-insensitive mutant (sail) of Arabidopsis thaliana identified in a selective screen utilizing the SA-inducible expression of the tms 2 gene. Molecule PlantMicrobe Interactions 1997, 10:69-78.

48. Lebel E, Heifetz P, Thorne L, Uknes S, Ryals J, Ward E: Functional analysis of regulatory sequences controlling $P R-1$ gene expression in Arabidopsis. Plant J 1998, 16:223-233.

49. Pegadaraju V, Louis J, Singh V, Reese J, Bautor J, Feys BJ, Cook G, Parker JE, Shah J: Phloem-based resistance to green peach aphid is controlled by Arabidopsis PHYTOALEXIN DEFICIENT4 without its signaling partner Enhanced disease susceptibility1. Plant J 2007, 52:332-341.

50. Byrd DW, Kirkpatrick T, Barker KR: An improved technique for clearing and staining plant tissue for detection of nematodes. J Nematol 1983, 15:142-143.

51. Haseloff J, Siemering KR, Prasher DC, Hodge S: Removal of a cryptic intron and subcellular localization of green fluorescent protein are required to mark transgenic Arabidopsis plants brightly. Proc Natl Acad Sci USA 1997, 94:2122-2127.

52. White FF, Taylor BH, Huffman GA, Gordon MP, Nester EW: Molecular and genetic analysis of the transferred DNA regions of the root-inducing plasmid of A. rhizogenes. J Bacterio/ 1985, 164:33-44.

53. Elmayan T, Tepfer M: Evaluation in tobacco of the organ specificity and strength of the rolD promoter, domain $\mathrm{A}$ of the $35 \mathrm{~S}$ promoter and the 35 S2 promoter. Transgenic Res 1995, 4:388-396.

doi:10.1186/1471-2229-13-67

Cite this article as: Youssef et al:: Ectopic expression of AtPAD4 broadens resistance of soybean to soybean cyst and root-knot nematodes. BMC Plant Biology 2013 13:67.

\section{Submit your next manuscript to BioMed Central and take full advantage of:}

- Convenient online submission

- Thorough peer review

- No space constraints or color figure charges

- Immediate publication on acceptance

- Inclusion in PubMed, CAS, Scopus and Google Scholar

- Research which is freely available for redistribution 